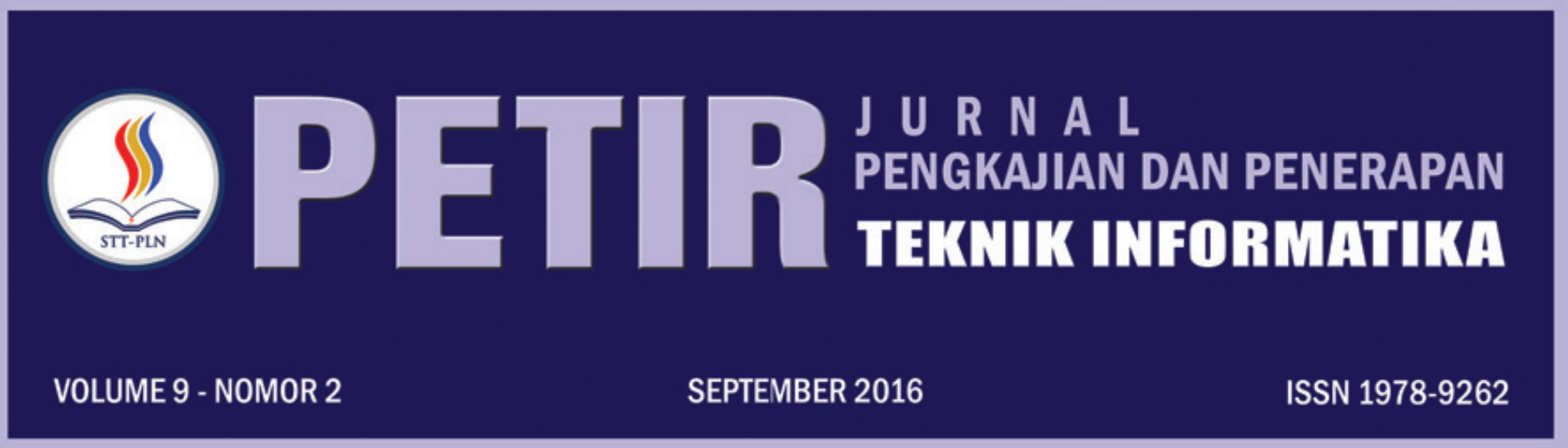

ANALISA SPASIAL UNTUK MELIHAT TINGKAT KESEJAHTERAAN MASYARAKAT DI PROVINSI BANTEN Muhamad Jafar Elly; Reza Pahlevi

PENENTUAN WILAYAH RAWAN PENYAKIT BERBASIS LINGKUNGAN DI JAKARTA TIMUR MENGGUNAKAN SISTEM INFORMASI GEOGRAFIS

Atiqah Meutia Hilda; Muhamad Jafar Elly; Windu Nugroho Cahyo Pamungkas

APLIKASI PENCARIAN USTADZ UNTUK WILAYAH DKI JAKARTA MENGGUNAKAN ALGORITMA HAVERSINE FORMULA BERBASIS ANDROID

Harni Kusniyati; Haries Fadhillah

PERENCANAAN ARSITEKTUR ENTERPRISE PERGURUAN TINGGI DENGAN PENDEKATAAN ENTERPRISE ARCHITECTURE PLANNING (EAP) (STUDI KASUS POLITEKNIK PIKSI GANESHA)

M. Farid Rifai

PERANCANGAN E-KATALOG PADA PERPUSTAKAAN DIGITAL STT-PLN BERBASIS WEB

Yessy Fitriani; Yasni Djamain; Risalatulina Dwi Kurniati

APLIKASI SISTEM GPS KEGIATAN OPERASIONAL PERSAMPAHAN DINAS PENGELOLAAN SAMPAH, PERTAMANAN DAN PEMAKAMAN (DP4) KOTA SUKABUMI

Yasmi Afrizal; Julian Chandra W
PERANCANGAN APLIKASI PENGOLAHAN DATA KAS BERBASIS ONLINE
(STUDI KASUS : KEMENTRIAN ' $X$ ')
Dian Hartanti; Lingga Desyanita

PERANCANGAN SISTEM INFORMASI PESERTA SERTIFIKASI

(Studi kasus LSP Piksi Ganesha)

Hendra Jatnika

RANCANG BANGUN APLIKASI SEC-WAY GUNA PENGINGAT BEPERGIAN DILENGKAPI INFO CUACA DAN CCTV JALAN RAYA LOKASI PILIHAN BERBASIS ANDROID STUDI KASUS DKI JAKARTA

Yasni Djamain; Intan Ratna Sari Yanti; Hari Wibowo

PREDIKSI PENERIMAAN SISWA BARU PADA MADRASAH ALIYAH AS-SAYAFI'IYAH 02 MENGGUNAKAN METODE TIME SERIES

Sarwo; Hermawan

PERANCANGAN SIMULASI MEDIA PEMBELAJARAN DENGAN METODE DIVISION REMAINDER UNTUK PENCARIAN ALAMAT RELATIF PADA PROSES PENEMPATAN DATA

Dewi Arianti Wulandari; Darma Rusjdi

ANALISIS SISTEM PENENTUAN LOKASI GANGGUAN JARINGAN DISTRIBUSI LISTRIK TERINTEGRASI GOOGLE MAP Abdul Haris; Herman Bedi Agtriadi

\begin{tabular}{|c|c|c|c|c|c|c|}
\hline \multirow{2}{*}{ 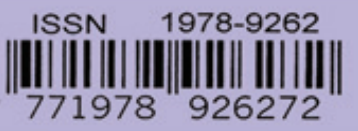 } & \multicolumn{6}{|c|}{ SEKOLAH TINGGI TEKNIK - PLN (STT-PLN) } \\
\hline & PETIR & VOL. 9 & NO. 2 & HAL. 89 - 166 & JAKARTA, SEPTEMBER 2016 & ISSN 1978-9262 \\
\hline
\end{tabular}




\title{
APLIKASI SISTEM GPS KEGIATAN OPERASIONAL PERSAMPAHAN DINAS PENGELOLAAN SAMPAH, PERTAMANAN DAN PEMAKAMAN (DP4) KOTA SUKABUMI
}

\author{
Yasmi Afrizal 1), Julian Chandra W ${ }^{2)}$ \\ Program Studi Sistem Informasi, Fakultas Teknik dan Ilmu Komputer, \\ UNIKOM Bandung
}

\begin{abstract}
Abstrak
Bertambahnya jumlah penduduk dan keragaman aktivitas di kota Sukabumi, mengakibatkan munculnya persoalan umum dalam pelayanan prasarana seperti angkutan persampahan. Selama ini proses pendataan dan pengawasan kendaraan operasional persampahan pada Dinas Pengelolaan Persampahan, Pertamanan dan Pemakaman (DP4) Kota Sukabumi tidak dapat dilakukan secara maksimal karena keterbatasan sistem informasi yang ada. Sehingga keberadaan kendaraan saat dilapangan tidak dapat diawasi secara langsung. Kurangnya pengawasan secara ketat dalam penggunaan fasilitas kendaraan operasional ini mengakibatkan terjadinya penyalahgunaan kendaraan dalam bekerja.

Penelitian yang dilakukan ditujukan untuk menemukan solusi permasalahan di atas dengan membangun aplikasi memonitoring kendaraan operasional persampahan dengan memanfaatkan teknologi GPS dan GIS, sehingga pihak yang berkepentingan khusus nya DP4 Kota Sukabumi dapat memantau pergerakan angkutan dan pengambil tindakan yang tepat jika terdapat kejadian selama perjalanan. Aplikasi yang telah dibuat dapat mempercepat proses pencarian posisi kendaraan operasional dan dapat mengetahui siapa yang mengoperasikan kendaraan tersebut tanpa melakukan pengawasan secara langsung ke lapangan, sehingga penyalahgunaan kendaraan operasional dapat dikurangi.
\end{abstract}

Kata Kunci : Kendaraaan Operasional Persampahan, GPS, GIS, DP4 Kota Sukabumi

\section{Abstract}

The increasing the number of population and the diversity activities in sukabumi caused the general problems on infrastructure service such as waste transportation. During the process of data collection and monitoring of waste operational vehicles at the Department of Waste Management, Parks and Cemeteries (DP4) of Sukabumi can not be done optimally because of the existing information systems limitations. So the presence of the vehicle where it in the field cannot be observed directly. The lack of strict supervision in the use of this operational vehicles facility caused the misuse of vehicles in the works.

This Research aimed to find the problems solutions by made an application for monitoring waste operational vehicles by utilizing GPS and GIS technology, so that the concerned parties especially DP4 of Sukabumi can monitor the movement of freight and make an appropriate decision if there are some problems that happen during the trip. The applications have been made to speed up the searching process of the vehicle operational position and to find out who operate these vehicles without directly supervision to the field, so that the misuse of vehicle operation can be reduced.

Keywords : waste operational vehicles, GPS, GIS, DP4 of Sukabumi

\section{Latar Belakang}

Bertambahnya jumlah penduduk dan keragaman aktivitas di kota Sukabumi, mengakibatkan munculnya persoalan umum dalam pelayanan prasarana perkotaan, seperti masalah pengangkutan sampah. Banyaknya sampah yang tidak terangkut kemungkinan besar tidak terdata secara sistematis, karena biasanya dihitung berdasarkan ritasi truk menuju TPA. Disamping itu tidak diduga adanya sampah yang ditangani masyarakat secara swadaya, ataupun sampah yang tercecer dan secara sistematis dibuang ke badan air. Paradigma angkutan persampahan seperti ini memiliki konsekuensi terhadap tingginya biaya operasional pengelolaan sampah karena sebagian besar biaya pengelolaan sampah digunakan untuk biaya pengangkutan.

Saat ini sampah di Kota Sukabumi dibuang ke lokasi TPA Cikundul di Kelurahan Situmekar,
Kecamatan Lembur Situ. Jarak lokasi dengan Kota Sukabumi relatif jauh yaitu sekitar $30 \mathrm{~km}$ dari pusat kota. Jarak yang jauh tersebut memiliki konsekuensi pada biaya operasional yang sangat tinggi untuk pengangkutan sampah yang sebagian besar digunakan untuk membeli bahan bakar kendaraan pengangkut. Oleh karena pengawasan rute dan sarana pengangkutan yang ada haruslah di monitoring untuk mendapatkan sistem pengangkutan yang baik sehingga dapat meminimalkan dampak terhadap lingkungan serta kerugian ekonomi.

Penerapan sistem manajemen angkutan kegiatan operasional persampahan merupakan suatu cara untuk mengelola dan mengorganisasi armada kendaraan yang dimiliki instansi yang mencakup aset fisik berupa kendaraan bermotor diantaranya adalah mobil dan truk. Sistem ini, dapat membantu mengetahui pergerakan kendaraan operasional dari satu tempat ke tempat 
lainnya, sehingga status penggunaan kendaraan dapat diketahui secara tepat.

Salah satu sistem dasar untuk menerapkan manajemen armada adalah perangkat pelacakan kendaraan GPS Tracking. GPS Tracking merupakan teknologi Automated Vehicle Locater (Penanda lokasi kendaraan secara otomatis) yang memungkinkan pengguna untuk melacak posis kendaraan, armada pengiriman barang, logistik, kontainer sampai kendaraan pertambangan dalam keadaan Real-Time. GPS Tracking memanfaatkan kombinasi teknologi Jaringan GSM dan Global Positioning System (GPS) untuk menentukan koordinat sebuah obyek, kemudian menerjemahkannya dalam bentuk peta digital.

Berdasarkan permasalahan diatas, Dinas

Pengelolaan Sampah, Pertamanan Dan Pemakaman (DP4) kota Sukabumi terus memperbaiki dan meningkatkan manajemen angkutan operasional persampahan. Teknologi informasi yang dapat diterapkan untuk manajemen angkutan kegiatan operasional persampahan adalah menggabungkan sistem Global Positioning System (GPS) dan Geografic Information System (GIS) berbasis web dengan visual grafis dapat menawarkan solusi yang sangat baik untuk menghadapi tantangan besar dalam kegiatan operasional persampahan. Gabungan penggunaan teknologi tersebut dapat memantau, menggendalikan pelacakan lokasi kendaraan operasional secara real time, sehingga memungkinkan pihak yang berkepentingan dapat mengendalikan dan mengambil tindakan dengan benar dan tepat.

Penelitian yang dilakukan memilki 2 (dua) tujuan yang ingin dicapai yaitu:

1. Terbangunnya Perangkat Lunak GPS guna memonitoring keberadaaan kendaraan operasional persampahan, sehingga pihak yang berkepentingan dapat memantau pergerakan angkutan dan pengambil tindakan yang tepat jika terdapat kejadian selama perjalanan

2. Menghasilkan data yang real time, tersedianya data dan infomasi monitoring kendaraan operasional persambahan yang sesuai kebutuhan, tepat, dan akurat

\section{Landasan Teori}

\subsection{Sistem Informasi Geografi}

Sistem Informasi Geografi adalah sebuah sistem untuk penyimpanan, penyimpanan citra, pengecekan, penggabungan, penganalisaan, menampilkan dan memanipulasikan data yang ada secara spasial dideskripsikan wujud bumi (Prahasta, 2002).

Secara umum, definisi Sistem Informasi Geografi (SIG) meliputi tiga komponen utama. SIG terdiri dari hardware, software, dan prosedurprosedur yang sesuai dengan yang ditentukan. Komponen tersebut juga menjelaskan bahwa SIG menggunakan data yang dideskripsikan secara spasial atau yang secara geografis (Sunyoto, 2007).

Sistem Informasi Geografi adalah sebuah sistem untuk penyimpanan, penyimpanan citra, pengecekan, penggabungan, penganalisaan, menampilkan dan memanipulasikan data yang ada secara spasial dideskripsikan wujud bumi (Peter's dan Joe's, 2006).

\subsection{Data Spasial}

Setiap perangkat lunak SIG telah didesain untuk dapat mengatasi data spasial (disebut juga sebagai data geografis). Spasial data ditandai dengan informasi tentang posisi, hubungan dengan fitur lain, dan rincian dari karakter non-spasial. Contoh data spasial dari suatu stasiun cuaca bisa mencakup :

1. Lintang dan bujur sebagai referensi geografis. Jika garis lintang dan garis bujur dari sebuah stasiun cuaca telah diketahui, posisi relatif dari stasiun cuaca yang lain juga dapat diasumsikan, beserta dengan kedekatannya ke bukit dan daerah berbahaya.

2. Rincian hubungan seperti letak jalan, lift, dan jalur ski akan memungkinkan ahli meteorologi untuk mengakses ke stasiun cuaca.

3. Data non-spasial, sebagai contoh rincian jumlah salju, temperatur, kecepatan angin, dan arah.

\subsection{Peta}

Metode tradisional untuk menyimpan, menganalisis dan menyajikan data spasial adalah peta. Peta adalah dasar yang penting dalam SIG sebagai sebuah sumber data, struktur dalam penyimpanan data dan alat untuk menganalisis dan menunjukkan.

Pada umumnya, peta dibedakan atas peta tematik (thematic map) dan peta topografi (Prahasta, 2002). Peta tematik menunjukkan data yang berhubungan dengan tema atau topik tertentu, seperti tanah, geologi, geomorfologi, penggunaan lahan, populasi atau transportasi. Peta topografi mengandung kumpulan data yang bervariasi dalam topik yang berbeda-beda. Oleh karena itu, penggunaan lahan, relief,dan fitur kultural dapat ditampilkan semuanya dalam peta topografi yang sama.

\subsection{Garis Lintang dan Garis Bujur}

Garis lintang (latitude) dan garis bujur (longitude) adalah garis-garis khayal di permukaan bumi yang dilukis di atas peta, atlas atau bola dunia untuk membantu menunjukkan kedudukan suatu tempat. Letak dan posisi tempat dirujuk oleh titik persilangan (koordinat) antara garis lintang dengan garis bujur. Nilai garis lintang dinyatakan terlebih dahulu, kemudian diikuti oleh nilai garis bujur.

Garis lintang adalah garis-garis paralel pada bola dunia yang sejajar dengan Garis Ekuator. Garis lintang diukur dalam kiraan $\left(^{\circ}\right)$ dari Garis Khatulistiwa atau Ekuator $\left(0^{\circ}\right)$ tanpa sudut.

Garis bujur adalah garis-garis setengah lingkaran yang dilukis di sekeliling bola dunia dari bagian atas sampai ke bawah tegak lurus dengan garis lintang sehingga seolah-olah menghubungkan Kutub Utara dan Kutub Selatan. Hal ini juga berarti semua garis bujur bertemu antara satu sama lain di Kutub Utara dan Kutub Selatan karena setiap garis berawal dan berakhir di keduanya. 


\subsection{Global Positioning System}

Global Positioning System (GPS) merupakan sistem navigasi yang berbasiskan satelit dan merupakan alat untuk mengetahui posisi yang tersusun atas constellation 24 satellites yang mengorbit pada bumi pada ketinggian kurang lebih 11.000 mil (Fallon, 2000)

Pada GPS terdapat macam-macam elemen yang mendukung sebuah GPS (Baldus dan Kim, 2007) yaitu :

\section{Space segment}

Space segment merupakan bagian yang terdiri dari 24 satelit yang saling bekerja sama memantau keberadaan GPS receiver.

\section{Control Segment}

Control Segment merupakan pusat untuk mengontrol dan memonitor semua satelit yang ada agar memastikan semuanya bekerja dengan baik .Semua informasi ini diproses di MCS (Master Control Station).

\section{User Segment}

User Segment terdiri dari receiver-receiver yang secara khusus didesain untuk menerima, menterjemahkan dan untuk memproses sinyal dari satelit GPS yang ada.

\subsubsection{Cara Kerja GPS dalam Menentukan Posisi}

Prinsip dasar GPS terletak pada jarak dari receiver ke satelit, receiver minimal harus mencari 3 posisi satelit untuk menghasil posisi yang akurat, operasi ini dinamakan triangulation, secara singkat triangulation dapat

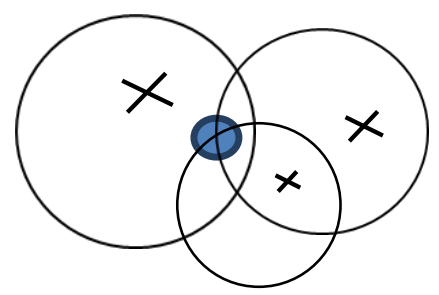

Gambar 1. Triangulation GPS (Schmidt, dkk, 2005)

Gambar 1 memperlihatkan ketiga satelit akan mencari irisan dari 3 posisi yang berbeda, posisi yang akurat akan ditemukan pada irisan ketiga satelit.

\section{Metodologi Penelitian}

Metodologi penelitian yang digunakan untuk membanguan Aplikasi Sistem GPS Kegiatan Operasional Persampahan Dinas Pengelolaan Sampah, Pertamanan dan Pemakaman Kota Sukabumi diperlihatkan pada gambar 2. sebagai berikut:

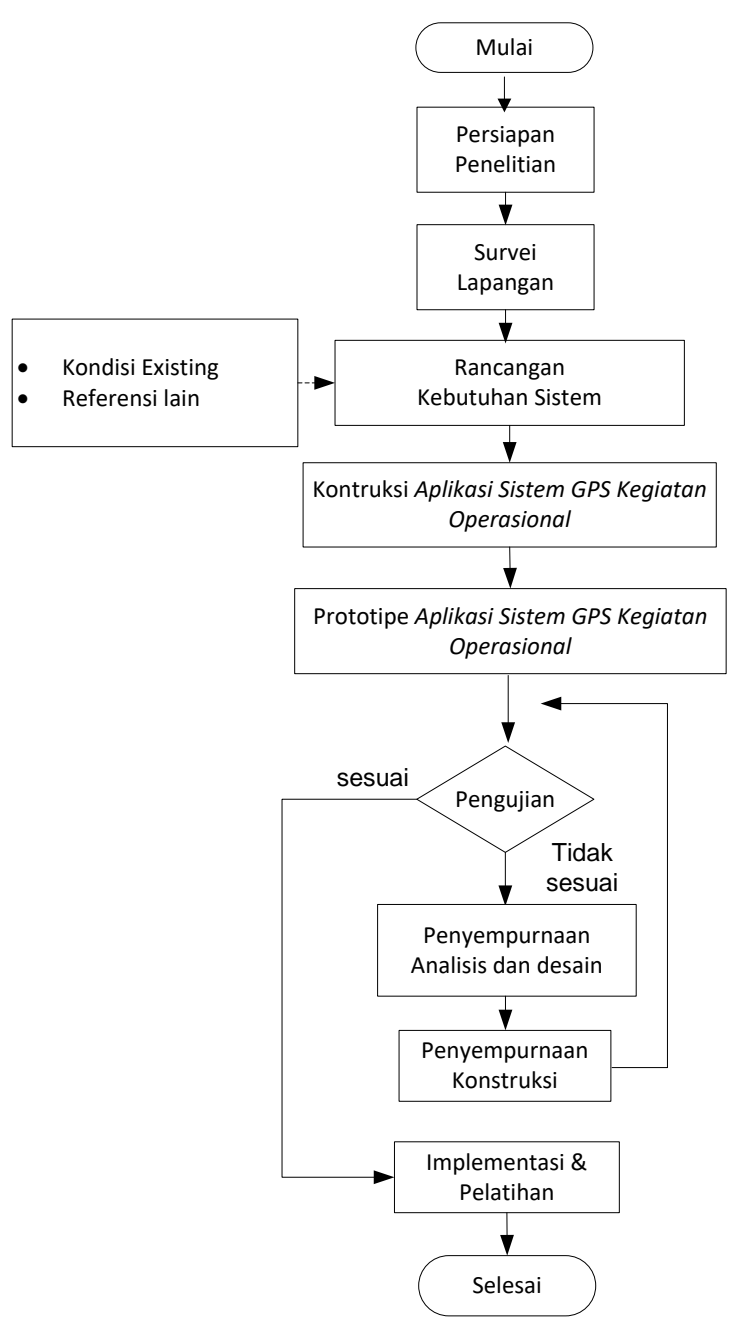

Gambar 2. Metodelogi Penelitian

Merujuk pada gambar 2 kegiatan pada tahap pengumpulan data dilakukan dengan melakukan survei langsung kelapangan dalam dengan responden Dinas Kota Sukabumi. Keluaran yang ingin dicapai dalam survei lapangan adalah mengenai:

\section{Kerja dari Sistem yang ada}

Langkah ini dilakukan dengan mempelajari sistem secara terinci untuk mengetahui bagaimana sistem beroperasi terdiri dari :

a. Data dan Informasi: Pengumpulan informasi mengenai proses pengolahan data hasil kegiatan, serta mengklasifikasikan seluruh jenis data dan menyampaikan konsep mekanisme flow of data.

b. Permasalahan: Mengumpulkan informasi mengenai kendala-kendala yang berhubungan dengan rencana pengembangan sistem.

\section{Menganalisa Hasil Penelitian}

Melakukan kegiatan lanjutan sesuai data yang telah diperoleh dari hasil penelitian yang telah dilakukan. Analisis yang dilakukan adalah :

a. Menganalisa prosedur sistem yang berjalan

b. Menganalisa dokumen 
c. Menganalisa Data dan informasi yang mengalir

d. Menganalisa keandalan sistem

4. Hasil Survei dan Perancangan Sistem

4.1 Analisis Sistem Yang Sedang Berjalan Sistem yang sedang berjalan di Dinas

Pengelolaan Persampahan, Pertamanan dan Pemakaman Kota Sukabumi bisa di katakan saat ini masih bersifat manual. Mulai pendataan data para supir, data TPS dan data kendaraan operasional masih dibuat dalam bentuk formulir. Begitu pula dalam hal kendaraan operasional tersebut masih secara manual hanya menggunakan form tertulis. Begitu juga dalam hal pengawasan kendaraan operasional tidak dapat dilakukan karena keterbatasan sistem informasi yang ada. Sehingga dalam hal keamanan kendaraan pada saat dilapangan tidak dapat diawasi secara langsung. Kurangnya pengawasan secara ketat dalam penggunaan fasilitas kendaraan operasional kantor mengakibatkan kurangnya disiplin dalam bekerja.

\subsection{Permasalahan yang Dihadapi}

Dari hasil analisis yang dilakukan pada Dinas

Pengelolaan Persampahan, Pertamanan dan Pemakaman Kota Sukabumi mengenai sistem yang sedang berjalan, maka terdapat beberapa permasalahan yang dihadapi, antara lain:

a. Keterbatasan sistem informasi yang dimiliki Dinas Pengelolaan Persampahan, Pertamanan dan Pemakaman Kota Sukabumi, yaitu sistem Informasi tradisional, dalam hal ini dengan dilakukannya pengawasan secara langsung ke lapangan yang selama ini di kenal tidak efektif dan efisien, baik dalam hal waktu ataupun biaya operasional, sehingga kurangnya pengawasan penggunaan kendaraan operasional kantor.

b. Belum dibuat database yang menyimpan keterangan tentang kendaraan operasional kantor. Sampai saat ini belum ada database yang digunakan secara bersamaan untuk menyimpan keterangan mengenai kendaraan operasional kantor. Yang ada untuk saat ini hanyalah pendataan menggunakan microsoft excel yang dilakukan menjadi tugas pihak pengawasan inventaris dan operasional pada Dinas Pengelolaan Persampahan, Pertamanan dan Pemakaman Kota Sukabumi.

\subsection{Kebutuhan Data}

Tabel 1 dibawah ini disampaikan sejumlah kebutuhan data yang digunakan dalam Aplikasi Sistem GPS Kegiatan Operasional Persampahan.

Tabel 1. Kebutuhan Data

\begin{tabular}{|c|c|c|c|c|}
\hline No. & Jenis Data & Item Detail Data & Kegunaan Data & Sumber Data \\
\hline 1. & Jalan & $\begin{array}{ll}- & \text { Nama Jalan } \\
\text { - } & \text { Id_Type } \\
- & \text { Type } \\
\text { - } & \text { Derajat Lintang utara } \\
\text { - } & \text { Derajat Lintang selatan }\end{array}$ & $\begin{array}{l}\text { Merupakan } \\
\text { informasi mengenai } \\
\text { rute jalan }\end{array}$ & - Survey sekunder \\
\hline 2 & Kendaraan & $\begin{array}{ll}\text { - } & \text { NoPolisi } \\
\text { - } & \text { KdtmerkKendaraan } \\
\text { - } & \text { Tahun pembuatan } \\
\text { - } & \text { No. rangka } \\
\text { - } & \text { KdSopir } \\
\text { - } & \text { Rute jalan }\end{array}$ & $\begin{array}{l}\text { Berisi informasi } \\
\text { mengenai } \\
\text { kendaraan } \\
\text { operasional Dinas }\end{array}$ & - Survey sekunder \\
\hline 3 & Merk Kendaraan & $\begin{array}{ll}\text { - } & \text { KdMerkKendaraan } \\
\text { - } & \text { NamaMekKendaraan } \\
\text { - } & \text { KdJenisKendaraan }\end{array}$ & $\begin{array}{l}\text { Berisi informasi } \\
\text { mengenai Jenis } \\
\text { Kendaraan } \\
\text { Operasional Dinas }\end{array}$ & - Survey sekunder \\
\hline 4 & Sopir & $\begin{array}{ll}- & \text { KdSopir } \\
\text { - } & \text { NamaSopir } \\
\text { - } & \text { Alamat } \\
\text { - } & \text { Tlp } \\
\text { - } & \text { Status Sopir } \\
\end{array}$ & $\begin{array}{l}\text { Berisi informasi } \\
\text { mengenai Sopir dan } \\
\text { penanggung jawab } \\
\text { kendaraan } \\
\text { operasional }\end{array}$ & - Survey sekunder \\
\hline 5 & $\begin{array}{l}\text { Opersi } \\
\text { Kendataan }\end{array}$ & $\begin{array}{ll}- & \text { NoPolisi } \\
\text { - } & \text { NamaSopir } \\
\text { - } & \text { Tanggal beroperasi } \\
\text { - } & \text { Waktu mulai beroperasi } \\
\text { - } & \text { Tanggalselesai beroperasi } \\
\text { - } & \text { Waktu selesai beroperasi } \\
\text { - } & \text { Berat sampah } \\
\end{array}$ & $\begin{array}{l}\text { Berisi informasi } \\
\text { mengenai } \\
\text { operasional } \\
\text { Kendaraan }\end{array}$ & - Survey sekunder \\
\hline 6 & $\begin{array}{l}\text { Tempat } \\
\text { Pembuangan } \\
\text { sampah }\end{array}$ & $\begin{array}{ll}\text { - } & \text { No. TPS } \\
\text { - } & \text { Nama Jalan } \\
\text { - } & \text { Tahun Pembuatan } \\
\text { - } & \text { Daya Tampung } \\
\text { - } & \text { Jenis TPS } \\
\end{array}$ & $\begin{array}{l}\text { Berisi informasi } \\
\text { mengenai TPS }\end{array}$ & - Survey sekunder \\
\hline
\end{tabular}




\subsection{Perancangan Aplikasi Sistem GPS} Kegiatan Operasional Persampahan

Pemecahan masalah yang dapat digunakan Dinas Pengelolaan Persampahan, Pertamanan dan Pemakaman Kota Sukabumi untuk mengawasi dengan ketat penggunaan inventaris dan kendaraan operasional tersebut, antara lain:

a. Dilakukan analisis secara spasial dengan menerapkan Sistem Informasi Geografi. Dengan adanya penggunaan Sistem Informasi Geografi dan komponennya maka analisis secara spasial akan dapat dilakukan dan dilakukannya analisis secara spasial, hasil analisis yang diperoleh dapat lebih optimal, yaitu dapat dilakukan analisis lebih mendalam dengan adanya informasi yang ditunjukkan lewat peta, grafik, dan sebagainya.

b. Menyediakan peta kota sukabumi untuk memantau secara manual letak-letak posisiposisi tiap jalan di sukabumi.

c. Membuat database mengenai kendaraan operasional kantor dan juga database jalan yang ada di kota sukabumi untuk menentukan posisi-posisi titik koordinat.

d. Penggunaan alat GPS (Global Positioning System) yang bisa memberikan informasi lokasi dengan akurat sehingga nantinya data penggunaan kendaraan operasional kantor bisa dianalisis secara detail penggunaannya.

Konteks Diagram merupakan gambaran dari aliran data sistem yang dibuat secara umum dari sudut panjang pengguna. Gambar 3 memperlihatkan konteks diagram Aplikasi Sistem GPS Kegiatan Operasional Persampahan secara keseluruhan.

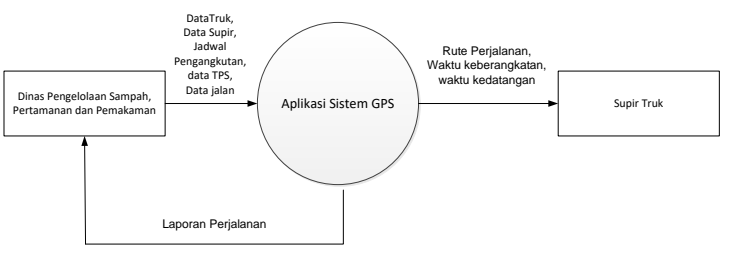

Gambar 3 Konteks Diagram Aplikasi Sistem GPS Kegiatan Operasional Persampahan

Dari gambar 3 di atas terlihat entitas pengguna Aplikasi Sistem GPS Kota Sukabumi adalah Petugas operasional DP4 Kota Sukabumi dan Supir Truk. Entitas pengguna tersebut dapat mengakses informasi yang dibutuhkan disesuaikan dengan kepentingan masing-masing entitas.

\section{Aplikasi Sistem GPS Kegiatan Operasional Persampahan \\ Aplikasi Sistem GPS Kegiatan Operasional} Persampahan Kota Sukabumi merupakan aplikasi yang berfungsi untuk pemantauan posisi kendaraan berbasis teknologi GPS, GIS dan rekam jejak / histori yang ditempuh oleh sebuah kendaraan untuk mencapai sebuah posisi tertentu.

Adapun manfaat yang dapat diperoleh adalah memudahkan para pemilik kendaraan dalam hal ini Dinas Pengelolaan sampah, Pertamanan dan pemakaman kota Sukabumi untuk mengetahui dan memantau posisi dari kendaraan mereka jika dikendarai oleh orang lain serta mengetahui rute dan rekam jejak/histori dari posisi yang dilalui kendaraan dalam mencapai sebuah posisi.

Aplikasi Sistem GPS Kegiatan Operasional Persampahan merupakan aplikasi Web yang terhubung dengan internet dan aplikasi ini hanya memerlukan memerlukan browser untuk dapat menjalankannya. Prosedur tata cara penggunaan aplikasi ini dimulai dengan munculnya layar pembuka dengan menu halaman Login yang terdiri dari "User Id" dan "Password" sebagai autentifikasi (gambar 4).

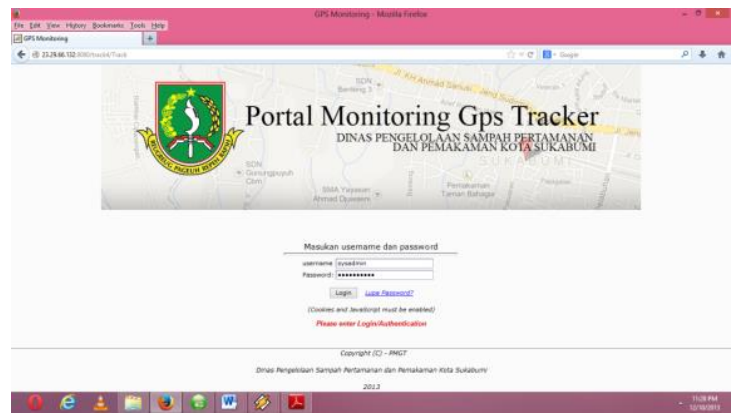

Gambar 4, Halaman Autentifikasi User

Masukkan Username dan Password ke dalam form login, agar dapat dapat masuk ke aplikasi GPS. Berikut tampilan home untuk user dengan akses level admin (gambar 5).

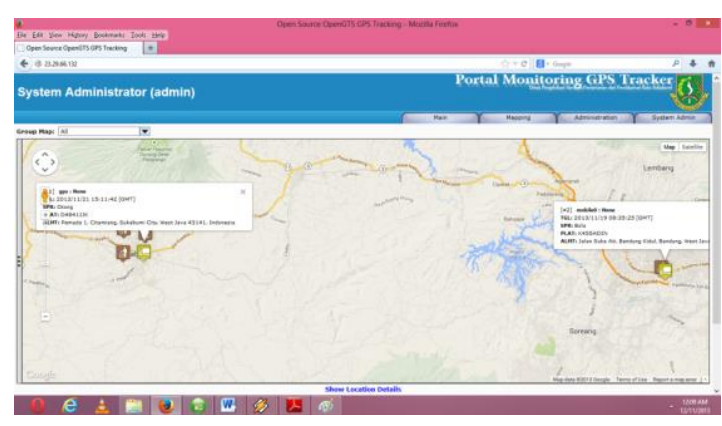

Gambar 5. Menu utama aplikasi GPS untuk Level Admin

Untuk melihat history rute kendaraan yang pada tanggal tertentu dilakukan dengan memilih tanggal perjalanan dan dilanjutkan no kendataaan. Gambar 6 memperlihatkan history rute kendaraan yang pernah dilakukan pada tanggal tertentu.

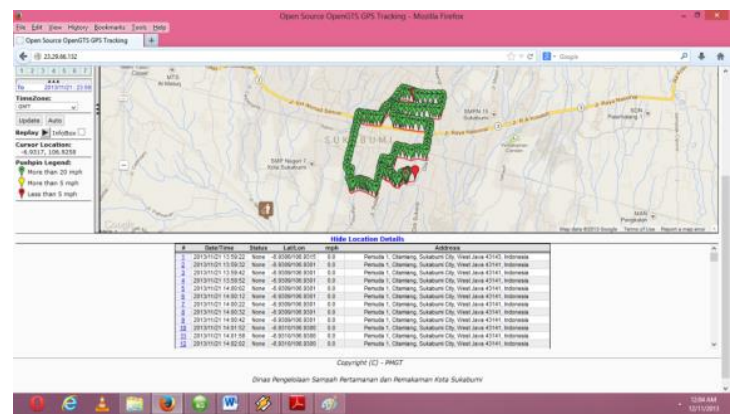

Gambar 5. History rute suatu kendaraan 
Selain daat memonitoring kendaraan operasional yang sedang melakukan akitifitas kegiatan pengankutan sampah, aplikasi ini memilki fasiltas untuk menempatkan titik dimanan lokasi TPS berada. Fasilitas ini penting untuk mengetahui apakah kendaraan operasional telah melalui atau mengangkut sampah pada lokasi TPS berada (gambar 6).

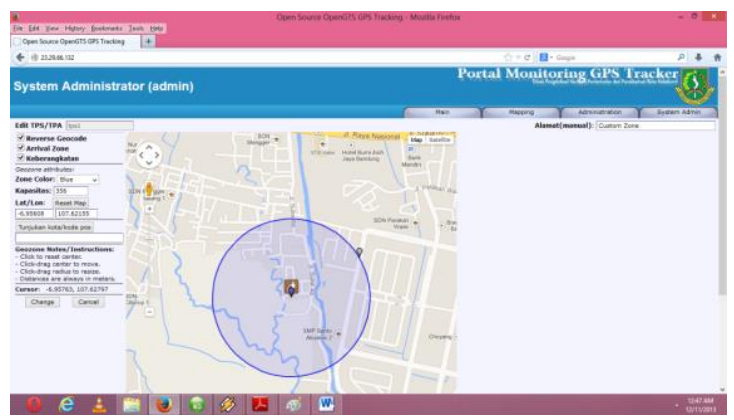

Gambar 6. Penempatan lokasi TPS pada Peta

\section{Kesimpulan dan Saran}

Sesuai dengan hasil analisa dan pembahasan yang telah dijabarkan pada pekerjaan ini, beberapa kesimpulan dapat diambil, sebagai berikut :

1. Aplikasi yang telah dibuat dapat mempercepat proses pencarian posisi kendaraan operasional dan dapat mengetahui siapa yang mengoperasikan kendaraan tersebut tanpa melakukan pengawasan secara langsung ke lapangan.

2. Memberi kemudahan Bagian Operasional di Dinas Pengelolaan Sampah, Pertamanan dan Pemakaman Kota Sukabumi dalam pengisian data operasional kendaraan dan mempercepat proses pengawasan penggunaan kendaraan.

3. Dengan adanya sistem ini, maka Bagian Operasional dapat memantau penggunaan kendaraan secara realtime dan juga mengurangi penyalahgunaan kendaraan operasional.

Berdasarkan kesimpulan di atas dapat diambil beberapa saran sebagai indikasi tidak lanjut yang harus dilakukan dalam rangka implementasi dan program aplikasi GPS kegiatan operasional Persampahan Dinas pengelolaan Sampah, Pertamanan dan Pemakaman kota Sukabumi. Beberapa rekomendasi studi meliputi:

1. Perlu diperhatikan terkait operasional penggunaan program aplikasi GPS kegiatan operasional Persampahan yaitu aspek keamanan dan pertanggungjawaban data dari perangkat lunak ini. Pihak yang berwenang harus memperhatikan beberapa faktor dan pertimbangan sebelum memberikan izin penggunaan perangkat lunak ini kepada pengguna (user)

2. Untuk mengikuti perkembangan sistem teknologi informasi yang cepat, program aplikasi GPS kegiatan operasional Persampahan kota Sukabumi dapat dikembangkan menjadi perangkat lunak yang dilengkapi dengan sensor RF untuk masuk dan keluarnya kendaraan, penambahan perangkat timbangan di TPA yang terhubung dengan perangkat lunak, Pemasangan CCTV serta perangkat lunak yang dapat diakses oleh pihak luar, namun dengan tetap memperhatikan tingkat pelibatan pihak luar dan tingkat penggunaan informasi.

3. Adanya SDM yang mempunyai keahlian dibidang IT dibutuhkan untuk mendukung penggunaan sistem dan teknologi informasi terutama di daerah sangat diperlukan. Oleh karena itu sebaiknya mulai dipikirkan mekanisme untuk menyediakan SDM di bidang IT untuk membantu penggunaan Aplikasi GPS ini.

\section{Daftar Pustaka}

Sunyoto, Andi., 2007, "Thesis: Integrasi Modul GPS Receiver dan GPRS untuk Penentuan Posisi dan Jalur Pergerakan Obyek Bergerak (Studi Kasus : Penentuan Posisi Taksi di Yogyakarta)", S2 Jurusan IImu Komputer, UGM, 2007.

Baldus, G. dan Kim J.,2007, "Collier County Government: Integrating GIS and Real-Time Vehicle Tracking for County Emergency Response", Naples, Florida.

Fallon, E., 2000, "Dublin Bus Tracking Service Design and implementation of a device independent passenger information", http://citeseer.ist.psu.edu/rd/79396097\%2C43 $5540 \% 2 \mathrm{C} 1 \% 2 \mathrm{C} 0.25 \% 2 \mathrm{CD}$ ownload/ftp\%3AqS qqSqftp.cs.tcd.ieqSqpubqSqtechreportsqSqreports.00qSqTCD-CS-200047.pdf, (Di download 26 Juni 2006).

Hasanuddin, A.Z., 1995., "Penentuan Posisi dengan GPS dan Aplikasinya". Pradnya Paramita. Jakarta.

Peter's dan Joe's, 2006, "NMEA Data", http://www.gpsinformation.org/dale/nmea.htm, 4 Dec 2006.

Prahasta, E., 2002 "Konsep-Konsep Dasar Sistem Informasi Geografis", Informatika, Bandung.

Schmidt, A., Holleis, P., Kranz, Matthias., Rukzio, E., 2005, "Accessing GPS Receiver from Mobile Phone Via Bluetooth", http://www.hcilab.org/documents/tutorials/BT GPS/BT GPS.htm, Ludwig-MaximiliansUniversity Munich, Desember 2005. 